\title{
OPERABILITY ASSESSMENT OF DRIVE SHAFTS OF JOHN DEERE TRACTORS IN OPERATIONAL PARAMETERS
}

\author{
Mikhail Erokhin ${ }^{1}$, Alexander Pastukhov ${ }^{2}$, Sergey Kazantsev ${ }^{1}$ \\ ${ }^{1}$ Russian Timiryazev State Agrarian University, Russia \\ ${ }^{2}$ Belgorod State Agricultural University, Russia \\ er.mihn@mail.ru,pastukhov_ag@mail.ru,kspts@bk.ru
}

\begin{abstract}
Operational observations of agricultural machinery are criteria-based assessment of reliability of their technical systems, in particular, of drive shafts of the John Deere 7830 tractors. 35 tractors, which are operated in the conditions of ordinary operation in the agrarian enterprises of the Belgorod region, Russia, were monitored. At the heart of experiment planning the observations of duration of the operating time and cross-section of loading of tractor engines according to the on-board computer with control of radial play in the joints of the drive shaft of the gearbox are put. The purpose - establishment of regularity of the size of radial play in cardan joints depending on the level of loading and duration of the operating time of the shaft in transmission of tractors at agricultural work. The technique of operational observations contained fixing of the following data: 1) control of the operating time of the tractor in physical hours according to onboard computer system; 2) measurement of radial play in the joints of the drive shaft by means of the developed device; 3) removal of the cross-section of loading of the engine on power at the measured torque and rotary speed of the crankshaft of the engine. As a result of statistical processing of the experimental data it is established: 1) average operating time of drive shafts of the observed tractors has made 4277 hours (share from selection is about $60 \%$ ); 2) loading of the drive shafts on the engine of the tractor averages $48.2 \mathrm{~kW}$ (share from selection is about $50 \%$ ); 3) average radial play in the joints of the studied drive shaft makes $0.350 \mathrm{~mm}$ (share from selection is about $50 \%$ ). For the purpose of studying of interconnection and influence of the experimental data on the basis of the multiple regression analysis the two-factor mathematical model of dependence of radial play in the function on loading and operating time is received.
\end{abstract}

Keywords: operability, drive shaft, operating time, loading, radial play.

\section{Introduction}

The problem of reliability of technical systems continues to remain as one of the main, despite continuous improvement of characteristics of durability, non-failure operation and maintainability of various parts, units and assemblies. This thesis is explained by the fact that the modern highly reliable equipment is used in conditions of tough operation on parameters of loading, operating time, technical conditions, etc. Owing to instability of production and service technological processes and also dispersion of parameters of technical condition it is necessary to make operational observations of the equipment for the purpose of establishment of real characteristics of reliability and parameters of technical conditions [1].

At stage of operation there is realization of reliability put and provided at the previous stages. Besides, the technical and economic consequences of low reliability leading to losses from equipment downtime to costs of eliminating failures and purchase of spare parts are shown. The complex of actions for reliability, which is carried out at this stage, includes realization and correction of maintenance of the operation system, periodic technical diagnosing of units, definition of residual resource and pre-failure condition, the analysis of causes of failures and organization of feedback with the producer [2;3].

Based on the trend of development of foreign agricultural tractors and technologies we note that the last fifth anniversary is characterized by significant progress in development and deployment of innovative technical solutions in tractor construction [4], however, this fact does not guarantee high reliability and at the same time cost efficiency of tractors in ordinary operation. In particular, according to researchers and production workers at high non-failure operation in the conditions of close climatic conditions and considerable volumes of work misfit of reliability of units and the recommendations of dealer service department of replacement interval of knots and units is observed [5].

In the agrarian enterprises of the Belgorod region of the Russian Federation tractors of foreign production are widely used, among them the leading position is held by the tractors of the brand John Deere, in particular, for 2006-2014 in the Russian Federation over 2.5 thousand pieces, from them about $10 \%$ are imported to the Belgorod region. By results of operation of the mentioned tractors researchers 
note their high operational reliability 15-20 thousand engine hours, average time between failures more than 1000 engine hours, the overstated cost of spare parts and dealer services $[2 ; 6]$.

According to observations it is noted that the John Deere tractors are operated in wide criteria range, have high operating time at low load of the engine and the main units of transmission. Among units, there are transmissions of the John Deere tractors of series 7030, the most responsible and the least durable is the drive line of the drive gear of the hydromodule of the gearbox, at the same time the shaft transfers the torque to $1000 \mathrm{~N} \cdot \mathrm{m}$ at the rotary speed of $1600-2100 \mathrm{~min}^{-1}$ with the corner of break $\pm 3^{\circ}$ that defines specifics, complexity and responsibility of refusal $[3 ; 7]$.

In practice of designing and operation of power knots of transmissions of tractors for assessment of the technical condition of the joints of drive lines in the course of the current diagnosing control the radial play in bearing mount assemblies at the corresponding operating time of the tractor and loading of drive lines [8].

The research objective - establishment of regularity of the size of radial play in cardan joints of the drive axis of the hydromodule of the gear box of the John Deere tractor from the level of loading and operating time under operating conditions.

For achievement of the goal it is necessary to solve the following problems:

1. collecting operational data on the operating time of tractors, loading of the shaft on the crosssection of loading of the engine and on current check of radial play at periodic diagnosing of the studied drive line;

2. processing of the experimental data and probe of multiple regression of radial play in joints as the operating time of the tractor and loading on the engine;

3. analysis and generalization of the received results.

\section{Materials and methods}

For evaluating the operational parameters characterizing the operating time, loading and technical condition of joints of the drive line of the drive gear of the hydromodule of the gearbox the observations of 35 tractors of the brand of John Deere of series 7030 in the agrarian enterprises of the Belgorod region during 2013-2016 were made [7].

The program of operational observations contained the following events: 1) statement of the purpose and tasks, drawing up technique; 2) identification of the tractor; 3) characteristic of conditions of carrying out observations and modes of behavior; 4) establishment of product indicators for collection of information; 5) purpose of frequency of inspections; 6) number of tractors and territorial location of the enterprises; 7) definition of methods of collecting and modes of information processing; 8) fixing of dynamics of parameters of the operating time, loading and technical condition; 9) formation of the commit protocol of observations results; 10) observation and identification of the reasons at emergence of refusals; 11) statistical processing of results; 12) formulation of conclusions.

For the purpose of reliable establishment of parameters of the operating time and loading of the drive line the mode of accounting of parameters on the basis of the data obtained by the service diagnostic the Service Advisor program is developed, in particular, the data of cross-section of loading of the engine for all operational cycle engaging were analyzed: rotary speed of bent shaft, transferred torque, operating time, fuel consumption, percentage component of loading. As a result the massif of basic data on each observed tractor for the studied factors of the operating time of $L$ and loading $N$ drive line on the engine was created. The observations were added with data presentation on the function of response in the form of radial district play $\Delta$ in cardan joints of the studied shaft of each tractor received by the results of assessment of their technical condition in the course of diagnosing [3;7]. Due to the passive nature of the two-factor experiment we fix levels of factors at the level of the received values.

Preliminary and main data processing is carried out in the form of descriptive statistics (arithmetic average $X$, median $M$, scope $R$, dispersion $S^{2}$, average quadratic deviation $S$, variation coefficient $v_{\mathrm{x}}$ ) and the multiple regression analysis (regression equation in the form of polynom of the second degree) [9], respectively, on the basis of computing algorithms of the "Analysis of Data" package of the tabular Microsoft Excel processor on formula (1): 


$$
Y=A_{0}+A_{1} X_{1}+A_{2} X_{2}+A_{3} X_{1}^{2}+A_{4} X_{1} X_{2}+A_{5} X_{2}{ }^{2},
$$

where $Y$-response function mathematical model;

$A_{0}, A_{1}, A_{2}, A_{3}, A_{4}, A_{5}$ - empirical coefficients;

$X_{1}, X_{2}$ - studied factors.

\section{Results and discussion}

The array of the basic data of parameters of drive lines on the operating time, loading and radial play in joints is presented in Table 1.

On the basis of preliminary data processing in the form of descriptive statistics on the operating time, loading and radial play the statistical characteristics and measures of dispersion of factors and the function of response presented in Table 2 are received.

Graphic interpretation of the data and results of descriptive statistics on the operating time, loading of shafts and radial play are presented in Fig. 1, 2 and 3.

Table 1

Data array of operational observations

\begin{tabular}{|c|c|c|c|c|c|}
\hline $\begin{array}{c}\text { Operating } \\
\text { time, hour }\end{array}$ & $\begin{array}{c}\text { Loading shafts, } \\
\mathbf{k W}\end{array}$ & $\begin{array}{c}\text { Radial play, } \\
\mathbf{~ m m}\end{array}$ & $\begin{array}{c}\text { Operating } \\
\text { time, hour }\end{array}$ & $\begin{array}{c}\text { Loading shafts, } \\
\mathbf{k W}\end{array}$ & $\begin{array}{c}\text { Radial play, } \\
\mathbf{m m}\end{array}$ \\
\hline 7473 & 67.1 & 0.374 & 10527 & 61.8 & 1.037 \\
\hline 10163 & 62.3 & 0.879 & 5700 & 57.5 & 0.695 \\
\hline 5724 & 56.7 & 0.601 & 5633 & 54.6 & 0.482 \\
\hline 7558 & 54.6 & 0.623 & 7488 & 44.3 & 0.377 \\
\hline 7811 & 53.6 & 0.632 & 4968 & 77.3 & 0.279 \\
\hline 2192 & 66.1 & 0.232 & 5067 & 47.7 & 0.396 \\
\hline 3537 & 64.7 & 0.423 & 748 & 61.6 & 0.089 \\
\hline 6784 & 46.4 & 0.257 & 532 & 64.6 & 0.050 \\
\hline 1724 & 60.7 & 0.189 & 7252 & 66.8 & 0.711 \\
\hline 9 & 21.4 & 0.026 & 7900 & 42.8 & 0.250 \\
\hline 10 & 19.4 & 0.025 & 8600 & 42.2 & 0.310 \\
\hline 4 & 17.1 & 0.028 & 5744 & 65.5 & 0.730 \\
\hline 6 & 16.2 & 0.023 & 1934 & 46.6 & 0.720 \\
\hline 11 & 18.2 & 0.031 & 2219 & 49.4 & 0.283 \\
\hline 5 & 16.1 & 0.019 & 14774 & 23.9 & 0.350 \\
\hline 7 & 17.1 & 0.017 & 250 & 37.5 & 0.042 \\
\hline 3685 & 68.9 & 0.343 & 1227 & 68.0 & 0.428 \\
\hline 2414 & 48.9 & 0.291 & - & - & - \\
\hline
\end{tabular}

Table 2

Results of preliminary statistical processing

\begin{tabular}{|c|c|c|c|}
\hline Parameters & Operating time, hour & Loading shafts, $\mathbf{k W}$ & Radial play, mm \\
\hline Arithmetic average & 4277 & 48.2 & 0.350 \\
\hline Median & 3685 & 53.6 & 0.310 \\
\hline Scope & 14770 & 61.2 & 1.020 \\
\hline Dispersion & 14365852 & 345.6 & 0.0765 \\
\hline Average quadratic deviation & 3790 & 18.6 & 0.277 \\
\hline Coefficient variation & 0.886 & 0.386 & 0.791 \\
\hline
\end{tabular}

The analysis of the data in Fig. 1 shows that these histograms of frequencies on the operating time are approximated by the polynominal curve of the 3rd order, at the same time the reliability of approximation - coefficient of determination is $R^{2}=0.8251$, the last demonstrates that the variability of frequencies is caused by $82.5 \%$ of the experimental data. 
Similarly, according to Fig. 2 and 3 we establish that histograms of frequencies of loading and radial play are approximated by the polynominal curve of the 3rd order with the coefficient of determination of $47.01 \%$ and $84.44 \%$, respectively.
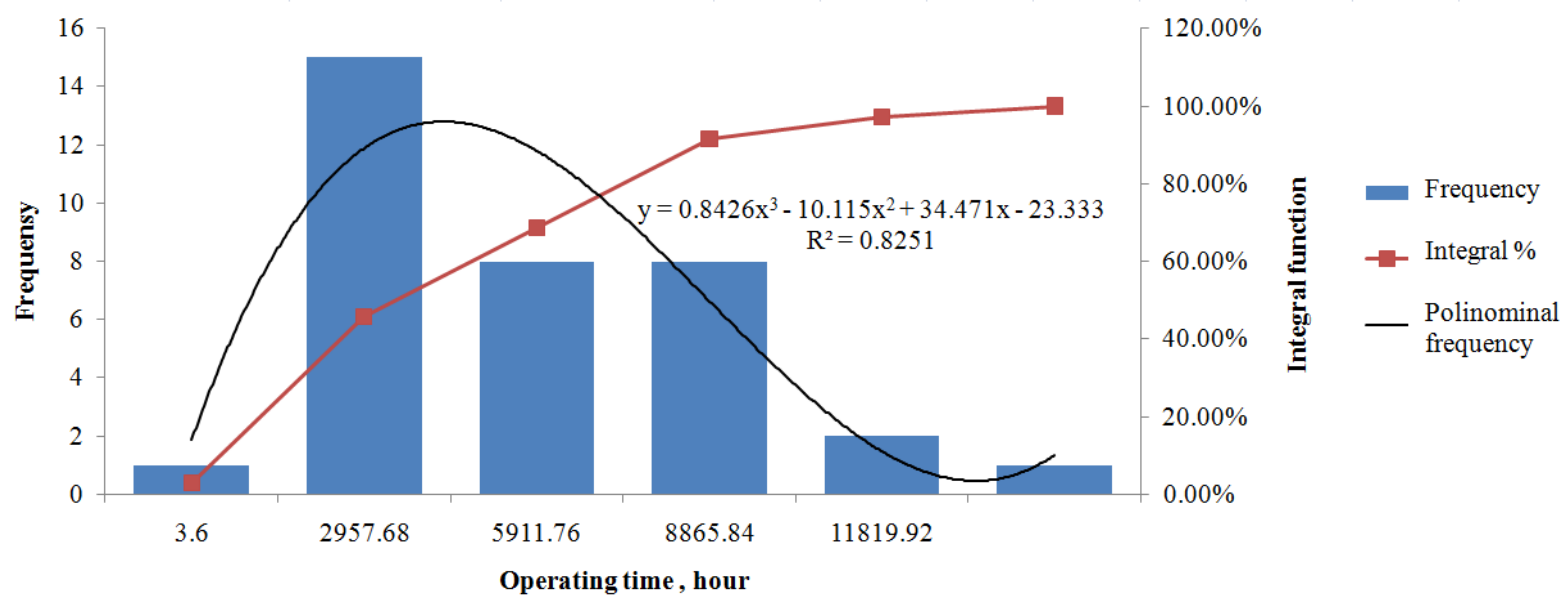

Fig. 1. Histogram of operating time

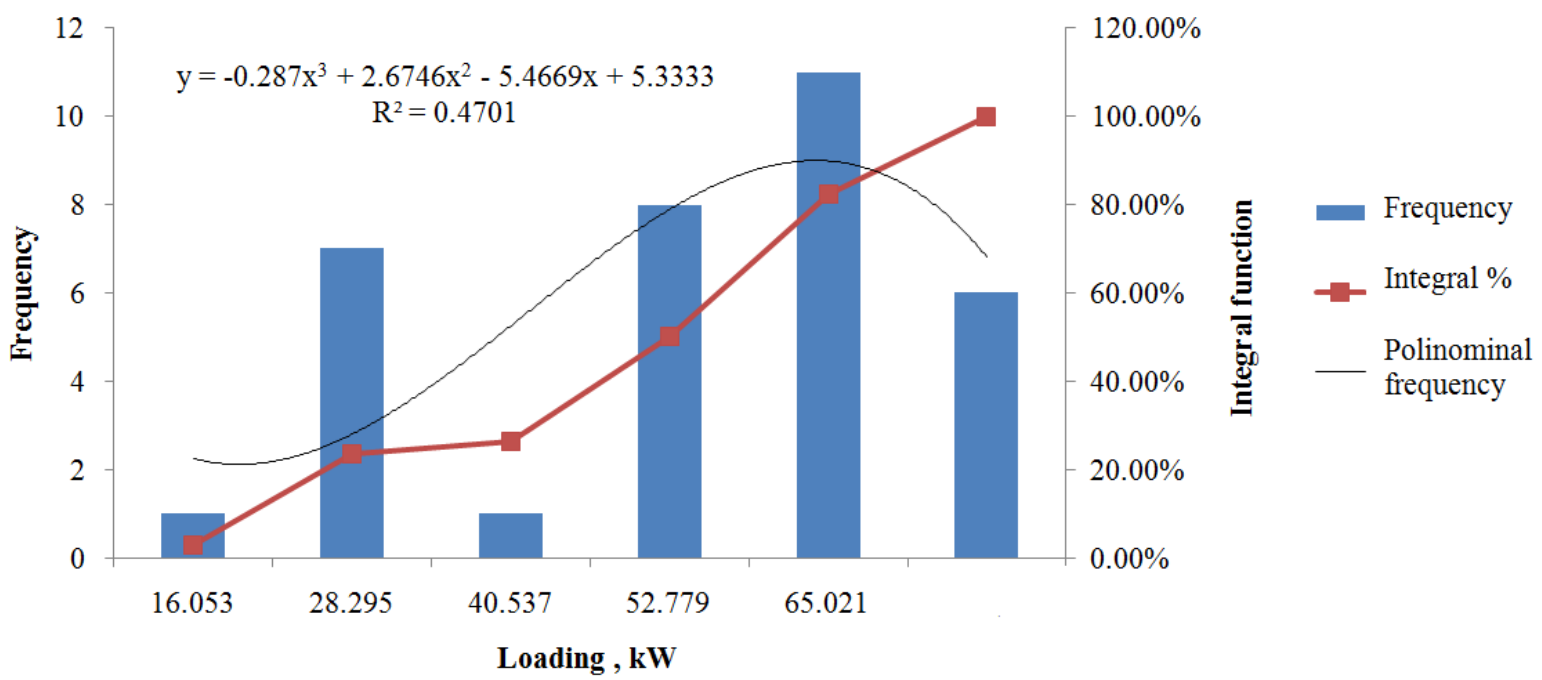

Fig. 2. Histogram of loading

The given results characterize the process of operation of the John Deere tractors with considerable operating time at non-uniform loading of units of transmission, therefore about a half of the observed tractors contain drive lines with residual resource that will be coordinated with the results of assessment of the technical condition of tractors according to the authors [10].

By results of the multiple regression analysis expression of dependence of radial play of $Y=\Delta, \mathrm{mm}$ in joints is received on the operating time $X_{1}=L$, hour, and loading of $X_{2}=N, \mathrm{~kW}$, drive line on the equation (1) in the decoded look (2)

$$
\Delta=-0.388-9.89 \cdot 10^{-5} L+2.82 \cdot 10^{-2} N+4.22 \cdot 10^{-9} L^{2}+1.99 \cdot 10^{-6} L N-2.96 \cdot 10^{-4} N^{2} \text {. }
$$

Graphic interpretation of dependence of radial play on the operating time and loading is presented in Fig. 4.

Indicators of reliability of approximation demonstrate: at the coefficient of multiple regression of $R=0.861$ the coefficient of multiple determination makes $R^{2}=0.742$ and shows that $74.2 \%$ of the experimental data define variability of the studied function of response from the studied factors. Empirical coefficients of the equation are significant by the Student's criterion $t(i)_{\text {calc }}>t_{\text {tabl }}$, and the equation of multiple regression is rather determined concerning the studied process by the Fischer's criterion $F_{\text {calc }}=16.640>F_{\text {tabl }}=2.545$ at $95 \%$ probability. 


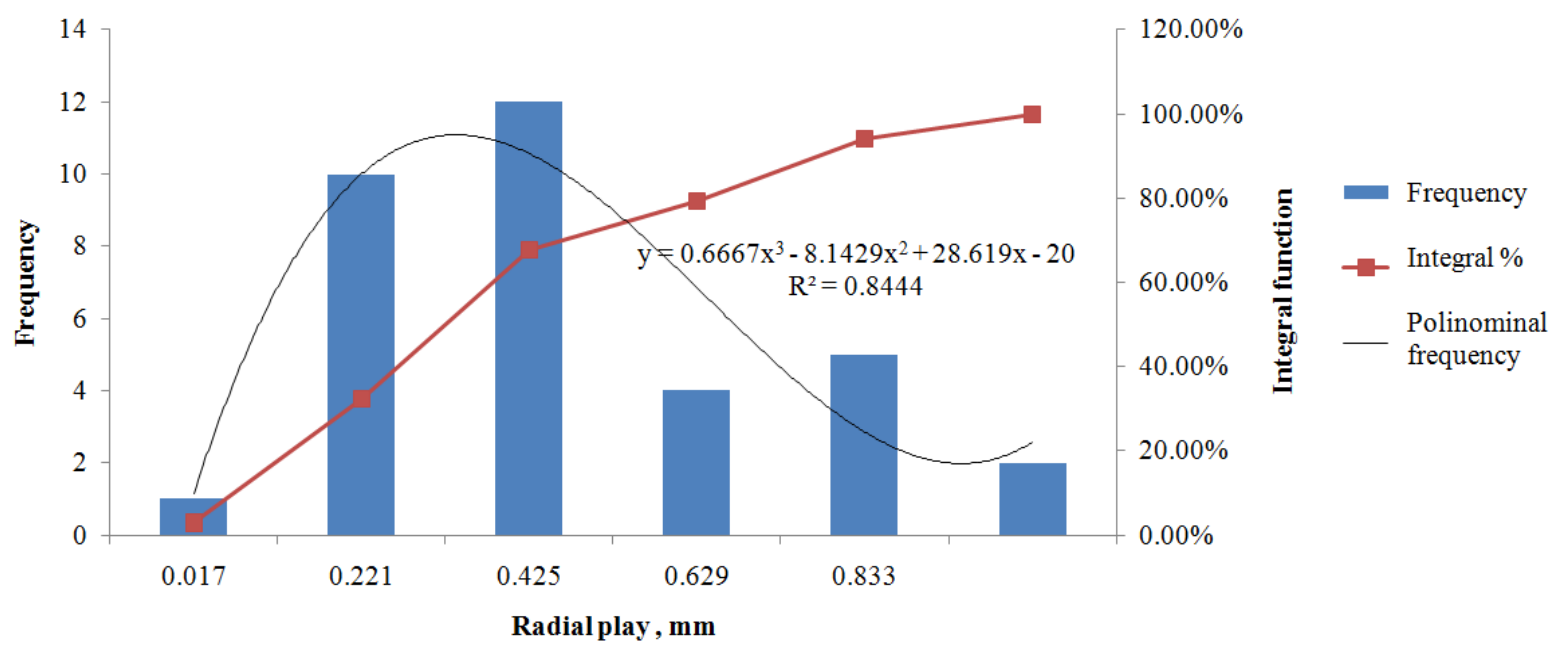

Fig. 3. Histogram of radial play

Analysis of dependence (Fig. 4) shows: loading, and then the period of operation has the greatest impact on the technical condition of joints of drive lines of the observed tractors that causes their technical and economic efficiency. Especially it is necessary to consider the average level and dispersion of values of these factors, as it defines the dynamics of change of radial play in the cardan bearing mount assemblies that allows to form tactics and principles of innovative signature technical service for tractors [11]. The last, in turn, defines the strategy of updating of the engine and tractor fleet taking into account development of agricultural production and ensuring food security [12].
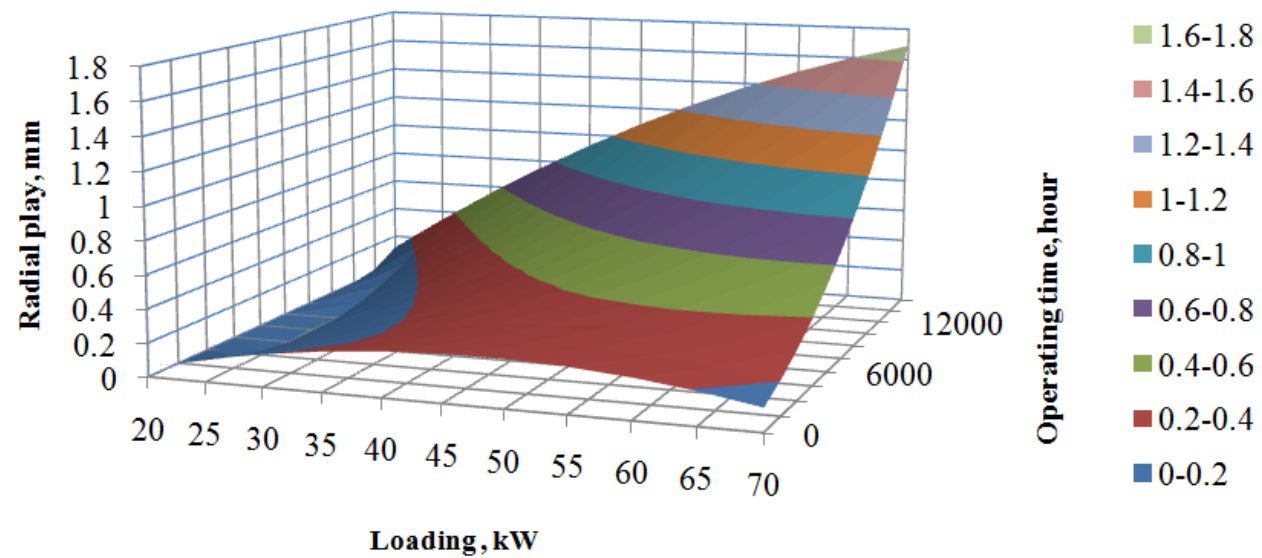

Fig. 4. Graphic interpretation of dependence radial play from operating time and loading

\section{Conclusions}

1. As a result of carrying out observations of the John Deere tractors of series 7030 in the conditions of ordinary operation the array of the experimental data on the operating time of tractors, their loading on the engine and radial play in joints is installed.

2. Statistical processing of the experimental data was carried out, as a result it is established that dispersion characteristics on the operating time and radial play do not exceed $80 \%$ and $90 \%$ is executed, and on loading there are limits of $40 \%$ of average value.

3. The analysis of graphic interpretation of histograms of frequencies of the operating time of tractors, loading of the shaft on the engine and radial play in joints shows:

- average operating time of tractors makes the 4277 hours, at the same time the share of the tractors having the operating time above makes about $40 \%$;

- loading of drive lines on the engine averages $48.2 \mathrm{~kW}$ that makes about $30 \%$ of the engine power, at the same time the share of tractors with higher loading makes about $50 \%$;

- average radial play in joints is $0.350 \mathrm{~mm}$, at the same time the share of joints exceeding this value is more than $50 \%$. 
4. Generalization of the results shows that at insufficient loading the studied drive lines of about a half of the observed tractors have residual resource that should be considered when carrying out scheduled works on maintenance operations.

5. Due to further development of agricultural equipment and technologies it is necessary to form reasonably the list of the acquired tractors and to carry out their rational operation on the basis of the planned uniform load.

\section{References}

[1] Lamberson L.R., Kapur K.S. Reliability in engineering design. Weliy India Pvt. Limited, 2009. $608 \mathrm{p}$.

[2] Гольтяпин В.Я. Тракторы фирмы John Deere. Тракторы и сельскохозяйственные машины. 2003. № 3. C.46-47. (Goltiapin B. J. Tractor company John Deere. Tractors and agricultural machinery. 2003. Vol. 3. Pp. 46-47) (In Russian)

[3] Ерохин М.Н., Пастухов А.Г. Надежность карданных передач трансмиссий сельскохозяйственной техники в эксплуатации: монография. Белгород: БелГСХА, 2008. 160 c. (Erokhin M.N., Pastukhov A.G. Reliability of drive lines of transmissions of agricultural machinery in operation: monograph. Belgorod: BelSAA, 2008. 160 p.) (In Russian).

[4] Федоренко В.Ф., Гольтяпин В.Я. Тракторы сельскохозяйственного назначения за рубежом: тенденции развития и инновационные разработки. Техника и оборудование для села. 2016. № 1. C. 2-7 (Fedorenko V.F., Goltyapin V.Ya. Tractors of agricultural purpose abroad: trends of development and innovative developments. Machinery and equipment for rural area. 2016. Vol. 1. Pp. 2-7) (In Russian)

[5] Кушнарев Л.И. К формированию и реализации концепции организации фирменного технического сервиса. Техника и оборудование для села. 2017. № 3. C.24-26 (Kushnarev L.I. On Forming and Implementation of Concept of Organization of Proprietary Technical service. Machinery and equipment for rural area. 2017. Vol. 3. Pp. 24-26) (In Russian)

[6] Габитов И.И, Портнов В.И. Особенности технического сервиса импортных мобильных сельхозмашин. Тракторы и сельскохозяйственные машины. 2007. № 1. C.53-64 (Gabitov I.I., Portnov V.I. Features of technical service of the import mobile agricultural machineryю. Tractors and farm vehicles. 2007. Vol. 1. Pp. 53-64) (In Russian)

[7] Erokhin M.N., Pastukhov A.G., Timashov E.P. Analysis of wear of the cardan cross the joints John Deere tractor. Novi Sad. Tractors and power machines. 2016. Vol. 21 (1). Pp. 24-29.

[8] Srivastava A.K., Goering C.E., Rohrbach R.P., Buckmaster D.R. Engineering Principles of Agricultural Machines. $2^{\text {nd }}$ Edition. ASABE, 2006. 553 p.

[9] Кобзарь А.И. Прикладная математическая статистика. Для инженеров и научных работников. М.: Физматлит, 2006. 816 с. (Kobzar A.I. Applied mathematical statistics. For engineers and scientists. M.: Fizmatlit, 2006. 816 p.) (In Russian)

[10] Galiev I., Khafizov C., Adigamov N., Khusainov R. Increase of Efficiency of Tractors use in Agricultural Production. Proceedings of 17th International Scientific Conference "Engineering for Rural Development", Vol. 17, Jelgava, 2018, pp. 373-377.

[11]Дидманидзе О.Н., Кушнарев Л.И. Состояние и направления инновационного развития инженерно-технической службы АПК. Международный технико-экономический журнал. 2014. № 1. C. 31-40. (Didmanidze O.N., Kushnarev L.I. State and directions of innovative development of engineering and technical service of agroindustrial complex. International technical and economic journal. 2014. Vol. 1. P. 31-40.) (In Russian)

[12] Viesturs D., Kopiks N. Trends in Development of Tractor fleet in Latvia. Proceedings of 16th International Scientific Conference "Engineering for Rural Development", Vol. 16, Jelgava, 2017, pp. 534-538. 